\title{
On Marta Breuer and some of her unpublished drawings of Drosophila spp. male terminalia (Diptera, Drosophilidae)
}

\author{
Carlos Ribeiro Vilela and Antonio Brito da Cunha \\ Departamento de Genética e Biologia Evolutiva, Instituto de Biociências, Universidade de São Paulo, \\ São Paulo, SP, Brazil.
}

\begin{abstract}
A short illustrated biography of Marta Erps Breuer (1902-1977), designer and lab technician at the University of São Paulo (Universidade de São Paulo), and a former Bauhaus student, is presented. Additionally, twenty fine China ink drawings of the male terminalia of twenty species of Neotropical Drosophila, made by her between October $4^{\text {th }}, 1951$, and March $24^{\text {th }}, 1959$, and currently deposited in the archives of the Department of Genetics and Evolutionary Biology of the Institute of Biosciences of the University of São Paulo (Departamento de Genética e Biologia Evolutiva, Instituto de Biociências, Universidade de São Paulo), São Paulo, State of São Paulo, Brazil, are included. All illustrated species but one are members of one of the following seven groups of the subgenus Drosophila: annulimana, canalinea, cardini, coffeata, dreyfusi, repleta, and tripunctata. Besides being depicted in the same position, the illustrations are so precise that we believe they will be extremely useful for those interested in Drosophila spp. identification. A comprehensive list of her scientific papers is included among the references.
\end{abstract}

Key words: Marta Breuer, André Dreyfus, aedeagus, Bauhaus, Neotropical region.

Received: February 10, 2006; Accepted: April 4, 2006.

\section{Introduction}

In the historical archives of the Departamento de Genética e Biologia Evolutiva (formerly Departamento de Biologia Geral), Instituto de Biociências, Universidade de São Paulo, São Paulo, State of São Paulo, Brazil, twenty fine original drawings of the male terminalia of twenty Neotropical species of Drosophila made by Marta Erps Breuer were found. They were donated to the archives in 1993 by Mrs. Emelde Konradi, who had received them from Milton Grellet, a close friend of Marta Erps Breuer.

Considering the scientific importance and the potential use of such material in studies of systematics and biodiversity of Neotropical Drosophila spp., we decided to publish them, as a tribute to her, together with a brief illustrated biography, partially based on Cunha (1977), of this artist-scientist who graduated from Bauhaus, the famous German school of design.

Although only the microscope slides of the terminalia of the specimens used for making the drawings were found in the Museu de Zoologia da Universidade de São Paulo, most of the drawings contain useful information, such as species identification and collection site, which were com-

Send correspondence to Carlos R. Vilela. Departamento de Genética e Biologia Evolutiva, Instituto de Biociências, Universidade de São Paulo, Caixa Postal 11461, 05422-970 São Paulo, SP, Brazil. E-mail: crvilela@ib.usp.br. mented, corrected, and updated in the figure captions whenever necessary. We believe their bodies were lost or, most probably, had never been preserved. About half of the illustrated specimens were obtained from strains provided by the National Drosophila Species Resource Center (NDSRC), formerly at the University of Texas at Austin and currently at the University of Arizona at Tucson (USA). Eleven out of the twenty drawings are as yet unpublished and the remaining nine, although previously published, have a different final touch, being less elaborated and more didactic. All of them are made with China ink and depict the whole male terminalia in right lateral view, with the aedeagi and aedeagal apodeme highlighted in black and the right paraphysis highlighted with dots. The illustrations are so accurate and skillfully drawn that, out of a total of 20 drawings of Drosophila species she depicted and most probably identified, there was only one whose previous identification we were unable to corroborate and/or to correct. It should be pointed out that five out of twenty species she illustrated were new to science by the time their terminalia were depicted, and one of them is most probably still undescribed.

To facilitate comparisons with published illustrations, the drawings were mirrored, slightly improved with Photoshop ${ }^{\circledR}$ and combined into plates, and their original handwritten notes and scale bars (irregularly positioned in 
addition to being absent in eight of them) were intentionally erased during the scanning process or afterwards, during image manipulation. However, new scale bars were added (those omitted were estimated) and, whenever relevant, the erased notes were included in the figure caption and/or discussion, together with information retrieved from two of Marta's sketchbooks, which are also deposited in the historical archives. According to her notes, all drawings but four were made under a $10 \mathrm{X}$ objective (under $15 \mathrm{X}=D$. mediopunctata, D. mediostriata and D. paranaensis; under $20 \mathrm{X}=D$. mercatorum). Whenever possible, strain code numbers were checked both with the unpublished Drosophila Species Stock List of December 12th, 1978, provided by the NDSRC, and with the lists published in the papers by Wasserman and Wilson (1957) and Throckmorton (1962). The strain numbers were also updated by checking The Tucson Drosophila Species Stock list (Arizona, USA), currently (December $1^{\text {st }}, 2005$ ) available online (http://stockcenter.arl.arizona.edu).

\section{A Short Biography}

Marta Magdalena Elisabeth Erps was born to Friedrich A.M. Erps and Auguste Mathilde J. Erps on September 29 ${ }^{\text {th }}, 1902$, in Frankfurt am Main, Germany. From 1921 through 1924, she attended classes at the Bauhaus, an important school of architecture, design and art, whose basic purpose was to integrate art and technology for the benefit of both disciplines. Founded originally in Weimar in 1919, the Bauhaus school was later (1925) transferred to Dessau, and then to Berlin (1932), where it was unfortunately closed forever the following year, when Hitler and the Nazis came to political power. The Bauhaus' legacy and its role in the evolution of techniques and ideas has long been recognized worldwide. During those times, Marta and her professor, the German architect Walter Gropius (founder of the Bauhaus), became good friends. She was also on good terms with other famous Bauhaus members such as Herbert Bayer, Andreas Feininger and Wassily Kandinsky.

On May $12^{\text {th }}, 1925$, Marta left Germany to visit her oldest brother Ludwig in Brazil, to where he had moved soon after World War I. Financed by his father, he had bought a small farm in the Atlantic tropical rain forest, between the municipalities of Miracutu and Juquiá (near the small towns of Cedro and Serrinha), about $135 \mathrm{~km}$ south of São Paulo City, southeastern São Paulo State. As far as it is known, she became completely fascinated with the life in a tropical country. One year later, on July $18^{\text {th }}, 1926$, she returned to Frankfurt and then immediately went to Paris, where she got married (on August $14^{\text {th }}, 1926$ ) to Marcel Lajos Breuer (1902-1981), a Hungarian and former colleague of her at Bauhaus, who would become one of the most influential architects and furniture designers of the $20^{\text {th }}$ century. A few years later, Marta Breuer came once again to Brazil and decided no longer to return and live in Europe. Meanwhile, Marcel Breuer moved to the United
States, where he became professor at The Harvard University, and in 1964 established in New York City a famous architectural office named "Marcel Breuer \& Associates, Architects". He designed some well-known public buildings, such as the UNESCO Headquarters (together with Bernard Zehrfuss) in Paris and the Whitney Museum of Art in New York. Few years later, their divorce was friendly finalized. For further information about Marcel Breuer, refer to his excellent biography written by Gatje (2000), his former partner.

After living for several years with her brother's family on a banana plantation farm near Cedro, where she worked hard as if she were a peasant, manually weeding with a hoe and a sickle, Marta moved to São Paulo City in 1932. There she had the opportunity to show her artistic abilities, especially by making fine drawings of cytological and histological preparations at a private institute created by two renowned physicians, Antonio Carini and Archimede Bussaca, for production and commerce of medicines and vaccines and located at Braulio Gomes street. Thanks to the work with those scientists, Marta was introduced to Prof. André Dreyfus and soon after she became his laboratory technician and drawer at the Escola Paulista de Medicina, where she met outstanding names of the Brazilian medicine at the time such as Edgard de Melo Mattos Barrozo do Amaral, Zeferino Vaz, Clemente Pereira and others.

While working at the Escola Paulista de Medicina (currently Universidade Federal de São Paulo), she also met Mr. Milton Grellet, then a student, who became her great friend. During this and the subsequent periods, besides tapestry and woodcarving, she made sculptures and paintings, although nobody but her close friends had the privilege to admire those works of art, which she kept at her home. Unfortunately, the whereabouts of the majority of those pieces are unknown.

On February $1^{\text {st }}, 1935$, by indication of Prof. Dreyfus, she was hired as a lab technician in the Science section of the newly-founded Faculdade de Filosofia, Ciências e Letras of the Universidade de São Paulo, then located on the third floor of the Faculdade de Medicina, on Avenida Dr. Arnaldo.

One year later (March 1936), funded by her family, she returned once again to Europe for a 6-month period, to become an expert in histological preparations and in tissue culturing. On coming back to Brazil, Marta Breuer (Figures 1-3) became a permanent partner of Prof. André Dreyfus until he prematurely died, aged 54, on February $16^{\text {th }}, 1952$. She had a great hand ability, technical creativity, accurate observation, dedication and research interests. In addition, her sensitivity and ability to reproduce the observed microworld in China ink drawings made her an exceptional technician and scientist. The archives of the Departamento de Genética e Biologia Evolutiva keep a wood-carved Drosophila melanogaster model constructed by Marta Breuer and concluded on May $12^{\text {th }}, 1959$ (Figure 4). This 


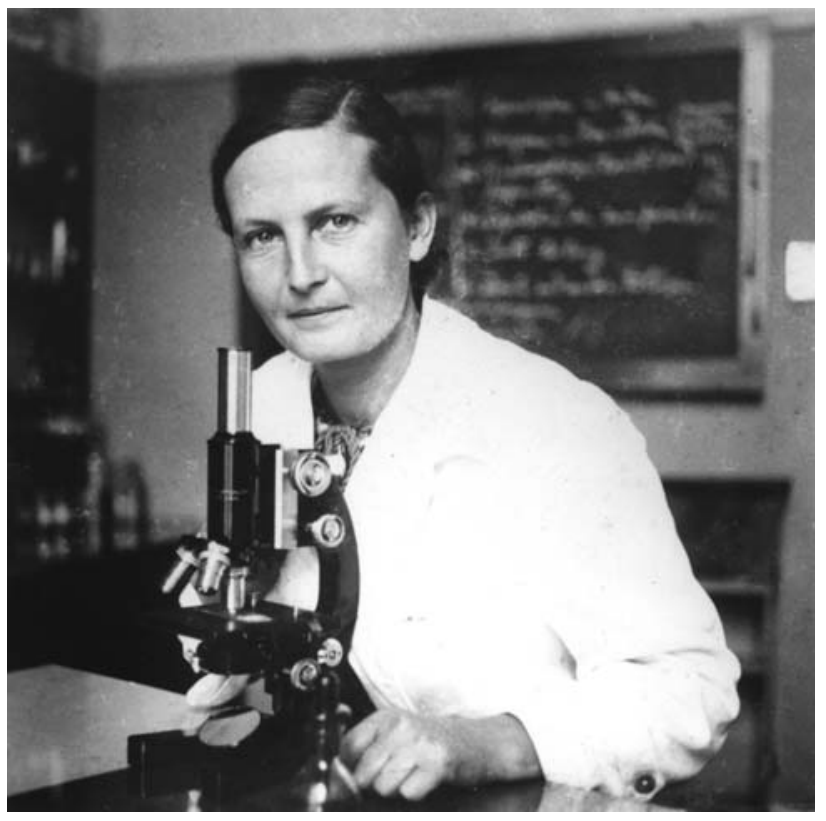

Figure 1 - Marta Erps Breuer in 1937 with her microscope, most probably at Dreyfus' lab in the Departamento de Biologia Geral, then on the third floor of the Faculdade de Medicina building (415 Dr. Arnaldo avenue), São Paulo city (SP), Brazil (M. Grellet phot.).

model helps, to our days, to introduce undergraduate students of the Instituto de Biociências to this famous organism so widely used in Genetics. A picture of this model and photocopies of most of her scientific papers are currently deposited at the world-famous Bauhaus - Archiv Museum für Gestaltung (http://www.bauhaus.de/), in Berlin.

Marta Breuer turned into a true scientist, even though she has never been given a formal degree in Science. Her career as a scientist spanned 28 years, during which she published 20 papers (see the references section below), four of them on her own, which combined both technical and artistic perfection.

Although she has often been considered as difficult to be dealt with, many biologists (Figure 2) who attended several disciplines in the old facilities of the then Departamento de Biologia Geral during the decades of 1940 and 1950, at that time located in the attic of a stately house at 463 Glete alley, Campos Elíseos district, remembered her with feelings of friendship and admiration.

Her collaboration with Dreyfus was fruitful, resulting in several important papers (Dreyfus and Breuer, 1944a, b; Dreyfus et al., 1951) concerning the species Rhabdias fülleborni and Telonomus fariai. At that time, it had already been widely accepted that the precise identification of Drosophila species required the analysis of the male terminalia morphology. Thus, in 1948, one of us (ABC) went to Rio de Janeiro City to learn the details of techniques for working on the terminalia of Diptera species with Prof. Hugo Souza Lopes at the Instituto Oswaldo Cruz, located at Manguinhos Farm. Upon returning to São Paulo, however, he had a feeling that making drawings was much above his

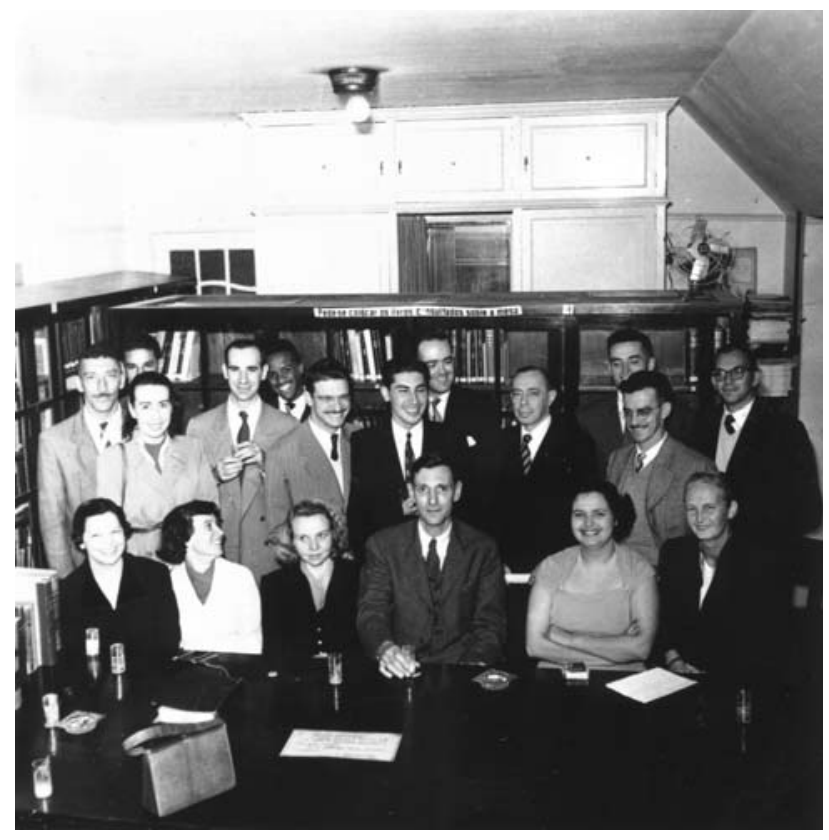

Figure 2 - From left to right, front row: Cândida de Paula Souza, Elisa Pereira Knapp, Ruth Ferri, Hampton Lawrence Carson, Lourdes Pavan, Marta Erps Breuer; second row: Rosa Brncic, Danko Brncic, Francisco Mauro Salzano, Juan Nacrur, André Dreyfus, Mario Guimarães Ferri; back row: Gabriel do Prado Bueno, Pedro Monteiro, Waldemar de Oliveira, Antonio Brito da Cunha, Walter Knapp, Edmundo Ferraz Nonato, in 1951, in the library of the Departamento de Biologia Geral in the attic of the house where it was located from 1938-1958 at 463 Glete alley, São Paulo city (SP), Brazil (C. Pavan phot.).

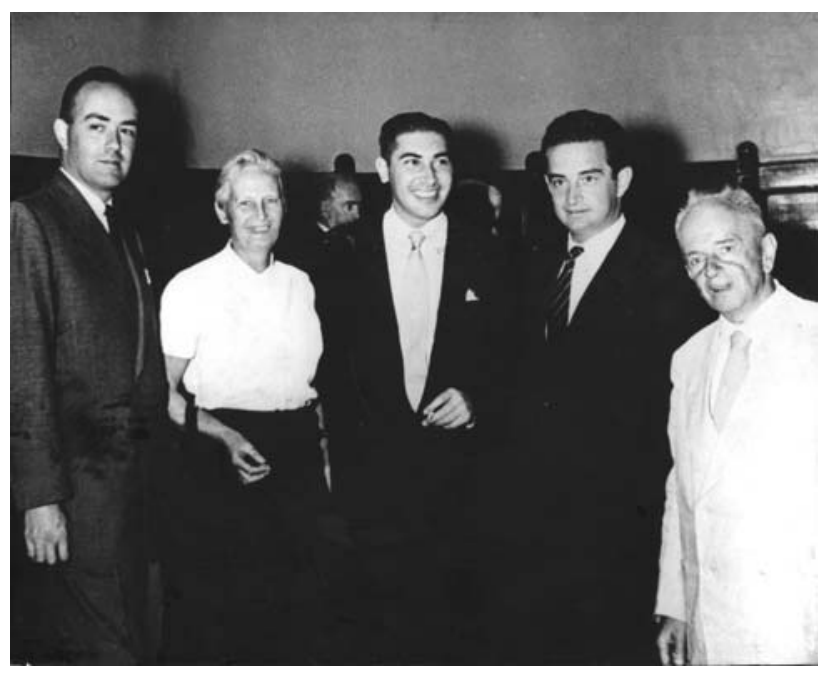

Figure 3 - From left to right: Antonio Brito da Cunha, Marta Erps Breuer, Juan Nacrur, Crodowaldo Pavan, Theodosius Dobzhansky, probably during the sessions of Pavan's Cathedra examination held on April 6-10 ${ }^{\text {th }}$, 1953, in the Main Building of the Faculdade de Filosofia, Ciências e Letras da Universidade de São Paulo (then at Rua Maria Antonia 294, São Paulo City (SP), Brazil).

capacity so he decided to transmit to Marta what he had learned about the techniques to make preparations of Drosophila terminalia, as well as about the specific nomenclature of their sclerites. She then started this new work with great interest. 

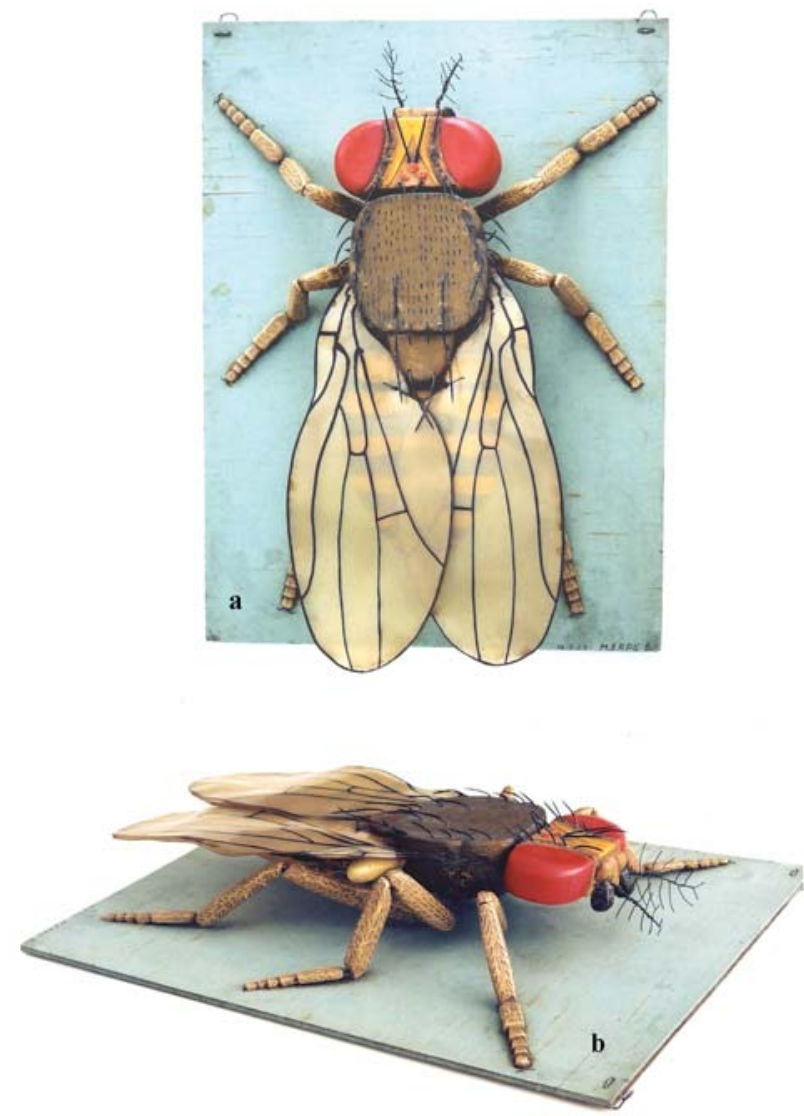

Figure 4 - Wood-carved female model of Drosophila melanogaster, constructed by Marta Erps Breuer and housed in the archives of the Departamento de Genética e Biologia Evolutiva, Instituto de Biociências, Universidade de São Paulo, São Paulo, SP, Brazil: a. dorsal view (note the date - May $12^{\text {th }}, 1959$ - and signature of Marta Erps Breuer in the lower right corner); b. lateroblique view (C. R. Vilela Phot.).

Subsequently, an important cooperation between Marta Breuer and Crodowaldo Pavan was initiated, leading to several projects, and resulting in essential papers in the fields of cytology, systematics and population genetics of Neotropical Drosophila species (Breuer and Pavan, 1950, 1954a; Pavan and Breuer, 1954). The exceptional quality of the drawings finely depicted by Marta Breuer has never been surpassed, and her style has undoubtedly inspired more than one generation of entomologists dedicated to systematics, including the senior author of the present paper. Her doubts were often clarified by the staff of the Departamento de Zoologia (currently Museu de Zoologia) then belonging to the Museu Paulista, mainly Nelson Papavero, and also by her own studies of the literature. In addition to her fine published drawings of the male genitalia of Drosophila and those still unpublished and presented hereinafter, Marta used to work with her colleagues at the Department, helping them with great interest and ability.

Soon after, led by Pavan, she started working on the polytene chromosomes of several species of flies belonging to the genus Rhynchosciara (Diptera, Sciaridae), resulting in papers that were considered fundamental to the development of cytogenetics. Crodowaldo Pavan and Marta Breuer unveiled the relationships between chromosomal puffs and gene function, describing for the first time the existence of DNA puffs, where synthesis with amplification of the genes they encompass occurs more markedly. They also showed that the genes are the same in all tissues of a given individual, however different genes are turned on, and even multiplied, in distinct tissues or even in the same tissue at different times during the development (Breuer and Pavan, 1952, 1954b, 1955; Pavan and Breuer, 1951, 1952, 1955a, b; Pavan et al. 1962; Breuer 1967a).

Marta's drawing of the distal end of one of the polytene chromosomes of Rhynchosciara americana (cited as angelae), associated with the respective photomicrographs, illustrated the cover page of the July-August 1952 issue (fascicle 4 of volume 43) of the Journal of Heredity.

During the subsequent decade, her interest went back to Systematics, at this time also including species of flies belonging to the genus Rhynchosciara, and she continued to publish exceptionally fine illustrated papers (Breuer, 1967b, 1969, 1971; Breuer and Rocha, 1971 [her last published paper, dated November $\left.30^{\text {th }}, 1971\right]$ ), or even to prepare some of them by request, as was the case of a paper describing a species of Drosophila that was named after her (Rocha, 1971).

Marta was a great enthusiast of field work, and her collaboration was precious to the population geneticists in collecting specimens of Drosophila spp.

Even after having officially retired on May $24^{\text {th }}$, 1966, she continued attending her office/lab (room No. 250) in the André Dreyfus building on the Cidade Universitária "Armando de Salles Oliveira" (CUASO), located in the west side of São Paulo city, until late 1971, when due to health problems she stopped to show up. For more than a decade she rode every day the long distance between her home, designed by herself, located at 61 (later 104) José Antônio Morais street, Jardim Petrópolis district (southern São Paulo city) and her office (at the CUASO), driving a grayish Volkswagen, a present from Marcel Breuer in the fifties.

Marta Breuer was viscerally against irrelevant publications, aimed to lengthen the authors' résumés instead of making significant contributions to the development of science. As a good German, she had no malice. She was an excellent companion in excursions and collecting trips. Sometimes her Germanic features could be embarrassing. One of us (ABC) clearly remembers what happened upon arriving by plane at the airport of Barreiras (State of Bahia, Brazil), more than 50 years ago: "The arrival of the plane was always a great happening to the mostly poor local population and the airport was crowded with people of all kinds. Soon after arriving at the airport, she asked me in a loud voice: Antonio, where is the money bag? 
Sometimes, however, she appeared not to be that naïve, as it had happened previously on a collection trip made in the State of Paraná. There was a hotel whose structure was entirely made of wood, the rooms were all in a row and separated by wooden walls. I (ABC) had been there other times and never found anything peculiar. However, the first morning, Marta called my attention to a peculiar finding. All the walls had a hole at the same position, a little above the middle of the beds. She thought somebody in the hotel was a voyeur. The same hotel had two cabins for sulfurous water baths, whose floors were made of movable laths. After two days of bathing, we were informed by a servant that a rattlesnake was always under the floor of one of the bathrooms. We went with him to the cabins, and there was indeed a snake sleeping just a short distance from where Marta's feet had been". But nothing would scare Marta, who was always ready to go collecting and enjoying all kinds of weird situations without any comfort, which would add to the novelty. She was a great artist, technician and a precious colleague in the work and life of the Departamento de Genética e Biologia Evolutiva of the Instituto de Biociências of the Universidade de São Paulo. Marta Breuer passed away on June $14^{\text {th }}, 1977$, aged 74 , and was buried at the Consolação cemetery, in downtown São Paulo City.

\section{The Original Drawings}

Twenty skillful original drawings of the male terminalia of twenty species of Drosophila (subgenus Drosophila), made between October $4^{\text {th }}, 1951$, and March $24^{\text {th }}, 1959$, by Marta Erps Breuer, are deposited in the archives of the Department of Genetics and Evolutionary Biology of the Institute of Biosciences of the University of São Paulo (Departamento de Genética e Biologia Evolutiva, Instituto de Biociências, Universidade de São Paulo), São Paulo, State of São Paulo, Brazil.

Nineteen of the twenty illustrated species undoubtedly belong to seven groups ascribed to the nominal subgenus of the genus Drosophila. Even though the remaining species seems to be still undescribed, and most probably belongs to the subgenus Drosophila as well, it could not be grouped. The 20 illustrated species, after having their identities confirmed and updated based on published drawings, are alphabetically arranged as follows:

annulimana group (Figure 5a-c): Drosophila aracataca Vilela \& Val, 1983 (Figure 5a); D. breueri Rocha, 1971 (Figure 5b) ; D. pseudotalamancana Pereira \& Vilela, 1987 (Figure 5c);

canalinea group: D. canalinea Patterson \& Mainland, 1944 (Figure 5d);

cardini group: D. neocardini Streisinger, 1946 (Figure 6a);

coffeata group: D. coffeata Williston, 1896 (Figure $6 \mathrm{~b})$; dreyfusi group (Figure 6c-d): D. camargoi Dobzhansky \& Pavan, in Pavan 1950 (Figure 6d); D. dreyfusi Dobzhansky \& Pavan, 1943 (Figure 6c);

repleta group (Figs. 7a-d, 8a-d, 9a): D. aldrichi Patterson, in Patterson \& Crow, 1940 (Figure 7a); D. buzzatii Patterson \& Wheeler, 1942 (Figure 7b); D. hydei Sturtevant, 1921 (Figure 7c); D. mercatorum Patterson \& Wheeler, 1942 (Figure 7d); D. mulleri Sturtevant, 1921 (Figure 8a); D. nigrospiracula Patterson \& Wheeler, 1942 (Figure 8b); D. paranaensis Barros, 1950 (Figure 8c); D. peninsularis Patterson \& Wheeler, 1942 (Figure 8d); D. rosinae Vilela, 1983 (Figure 9a);

tripunctata group (Figure 9b-c): D. mediopunctata Dobzhansky \& Pavan, 1943 (Figure 9b); D. mediostriata Duda, 1925 (Figure 9c);

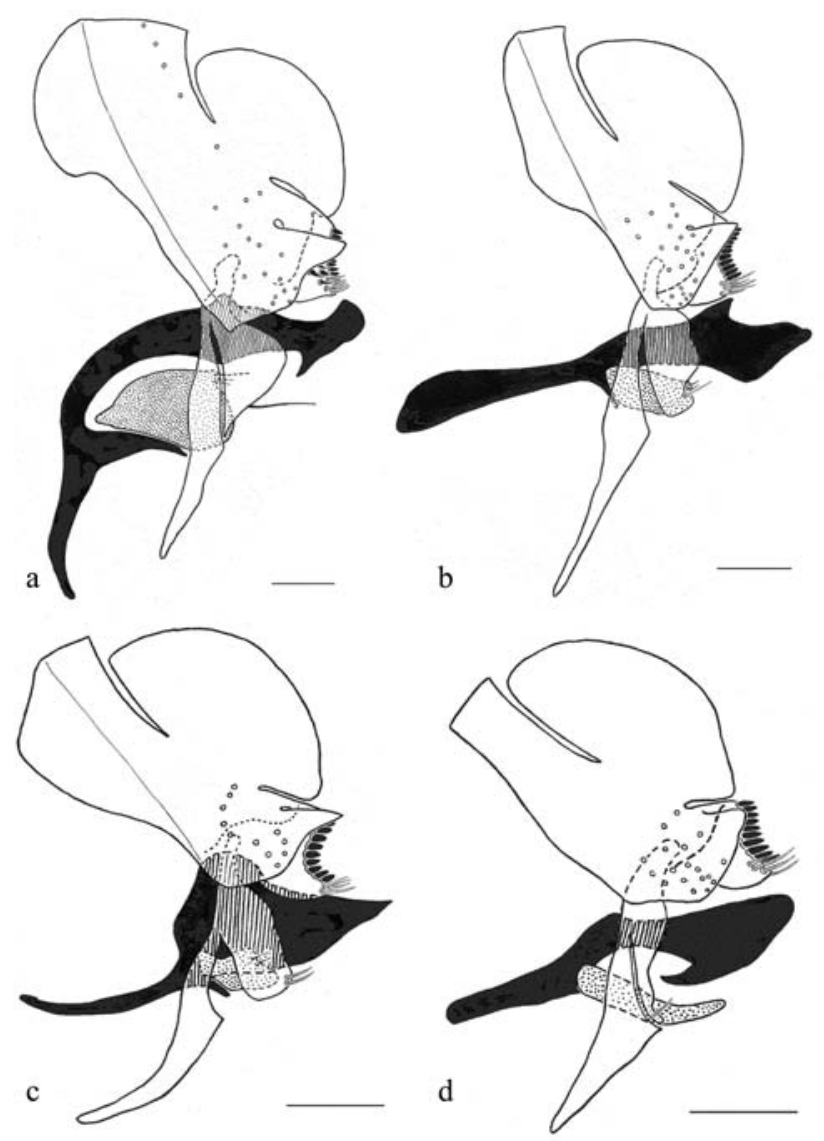

Figure 5 - Male terminalia (aedeagus + aedeagal apodeme are highlighted in black, and paraphysis is highlighted with dots), left lateral view, of: a. Drosophila aracataca Vilela \& Val, 1983; specimen from Volcan Boqueron, El Salvador (collection made in 1954; strain originally H42.38 [University of Texas], currently 15040-1171.02 [University of Arizona]). b. Drosophila breuerae Rocha, 1971; specimen from Colombia (probably Bucamaranga) (strain 101.24 [University of Texas]). c. Drosophila pseudotalamancana Pereira \& Vilela, 1987; specimen from La Palma (strain H62.37), or from San Salvador (collection made in 1955, strain H66.12 [University of Texas], currently 15040-1191.00 [University of Arizona]), El Salvador. d. Drosophila canalinea Patterson \& Mainland, 1944; specimen (no. 56) from Guaramiranga, state of Ceará, Brazil. Scale bars $=0.1 \mathrm{~mm}$. 
ungrouped: undetermined Drosophila sp. 1 (Figure 9d).

\section{Comments}

Regarding the probably undescribed Drosophila sp. 1 , the following information, which may be useful for future studies, has been retrieved from one of Marta Breuer's sketchbooks: The male specimen (there was probably only one) was collected at Angra dos Reis, State of Rio de Janeiro, Brazil, on an unspecified date (before March $2^{\text {nd }}$, 1959 [date of the terminalia drawing]); anterior scutellars divergent; main wing crossveins clouded; setae (and setulae?) arising from dark spots.

Only four out of the twenty drawings have no information regarding the collection site of the illustrated specimen. For four of the remaining 16, the following new records must be added to their geographical distribution.

Drosophila buzzatii is a South American cactophilic species that was introduced in the Palaearctic, Afrotropical and Australian regions following the intro-

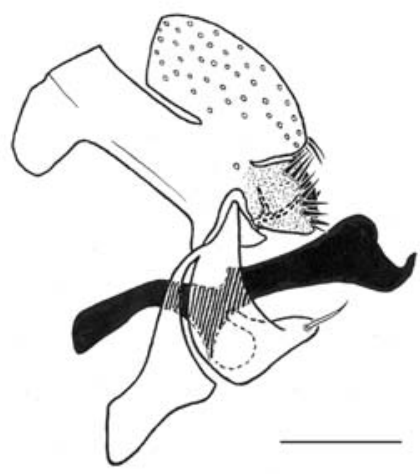

a
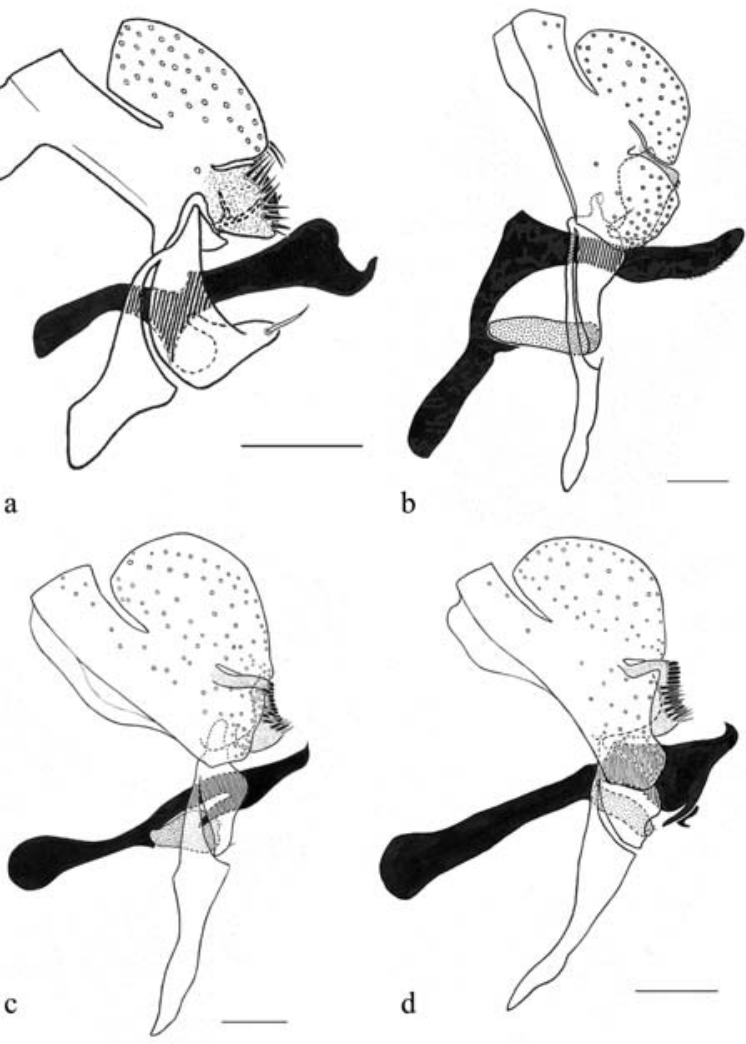

Figure 6 - Male terminalia (aedeagus + aedeagal apodeme are highlighted in black, and paraphysis is highlighted with dots), left lateral view, of: a. Drosophila neocardini Streisinger, 1946; specimen from Rio Negro, State of Amazonas, Brazil. b. Drosophila coffeata Williston, 1896; specimen from Vila Atlântica, Mongaguá, State of São Paulo, Brazil. c. Drosophila camargoi Dobzhansky \& Pavan, in: Pavan 1950; specimen from Panama, most probably no.15, (strain H80.5b [University of Texas]). d. Drosophila dreyfusi Dobzhansky \& Pavan, 1943; locality unknown. Scale bars $=0.1 \mathrm{~mm}$
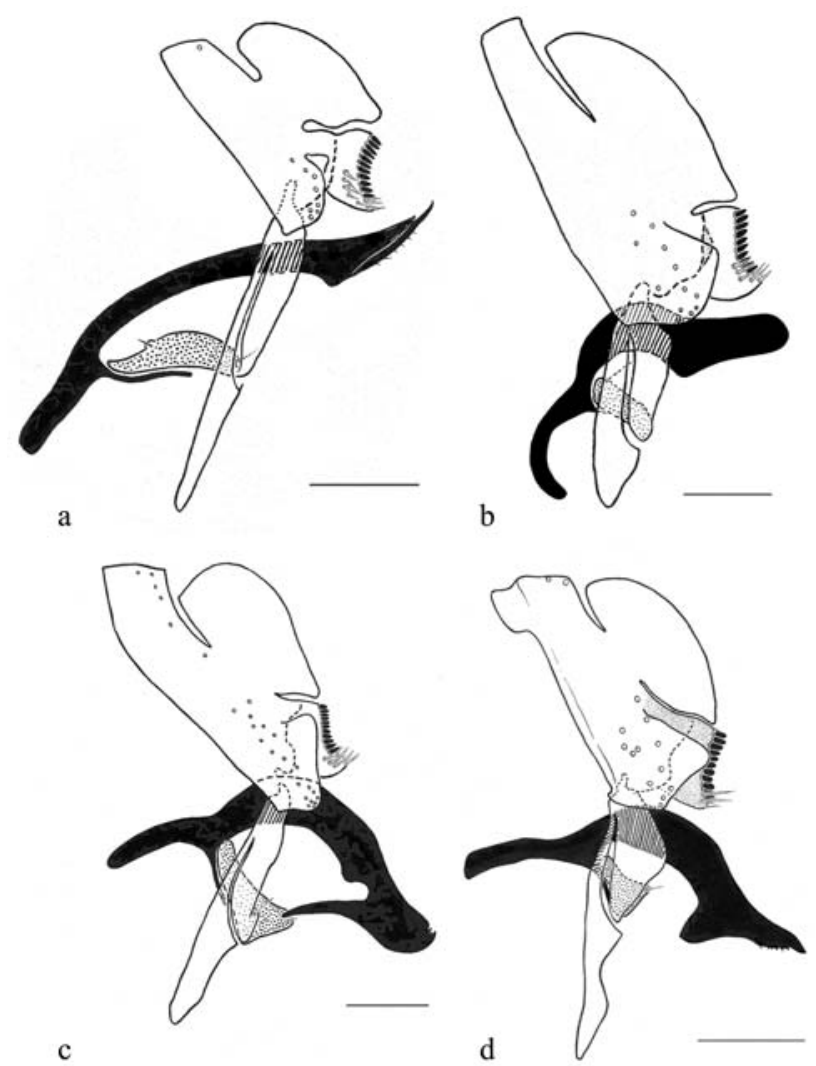

Figure 7 - Male terminalia (aedeagus + aedeagal apodeme are highlighted in black, and paraphysis is highlighted with dots), left lateral view, of: a. Drosophila aldrichi Patterson, in Patterson \& Crow, 1940; specimen (n. 24) from Mexico (strain 1781.4 [University of Texas]), or (n.22) from Puerto Triunfo, El Salvador, (strain H52.12 [University of Texas]). b. Drosophila buzzatii Patterson \& Wheeler, 1942; specimen (n. 28) from Corumbá, State of Mato Grosso do Sul, Brazil (strain 15.29 [University of Texas]). c. Drosophila hydei Sturtevant, 1921; locality unknown. d. Drosophila mercatorum Patterson \& Wheeler, 1942; specimen from Tijuca, Rio de Janeiro City?, State of Rio de Janeiro, Brazil. Scale bars $=0.1 \mathrm{~mm}$.

duction of the cactus Opuntia ficus-indica L. (Cactaceae). The illustrated specimen was collected at Corumbá, in the Brazilian State of Mato Grosso do Sul, where the fly had already been collected, but in other municipalities (Vilela, 1983:50). It should be pointed out that this specimen, whose terminalia were previously illustrated (Breuer and Rocha, 1971: 127), has been incorrectly cited as being from Colombia. However, the latter locality is corrected to read Corumbá in her handwritten notes, both in the original drawing and in her sketchbook, as well as on the microscope slide.

Drosophila canalinea, a widespread Neotropical species known from Mexico to Brazil (Wheeler, 1981:39), where it has been previously collected in the States of São Paulo, Goiás and Pará (Dobzhansky and Pavan, 1950:7), is recorded for the first time in Northeastern Brazil (Guaramiranga, State of Ceará). 
Drosophila paranaensis is a species of wide geographical distribution in the Neotropics (Wheeler, 1981:47). This species is recorded for the first time in the Peruvian Department of Huánuco (Tingo Maria). It has been previously collected in Peru (Pilares and Vásquez, 1977:104) only at La Merced-Chanchamayo (Department of Junin).

Drosophila rosinae is apparently endemic to the caatingas and strand vegetation of the Atlantic coast of South America. It has so far been collected only in the Brazilian States of Bahia, Minas Gerais, Espírito Santo, Rio de Janeiro and São Paulo (Vilela and Mori, 1999:326-327). The illustrated specimen, collected at Natal (Brazilian State of Rio Grande do Norte), represents a new and the northernmost record for this species.
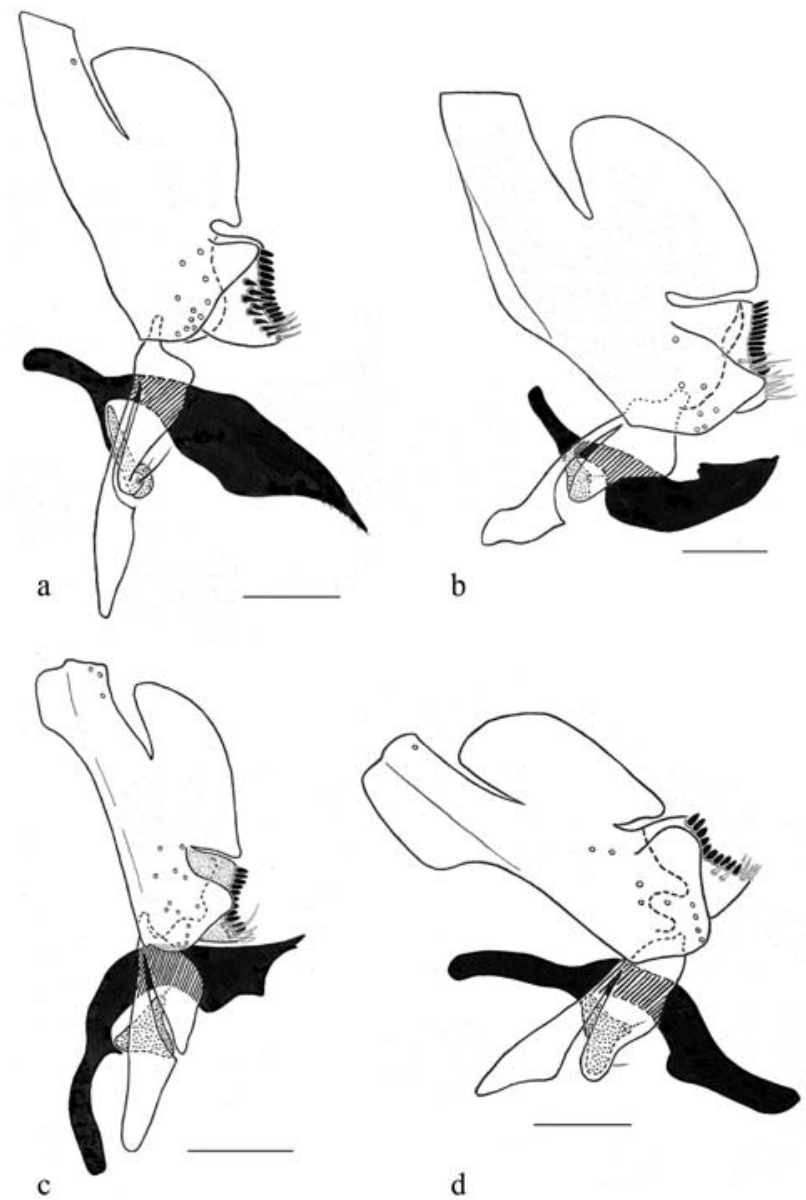

Figure 8 - Male terminalia (aedeagus + aedeagal apodeme are highlighted in black, and paraphysis is highlighted with dots), left lateral view, of: a. Drosophila mulleri Sturtevant, 1921; specimen from Roy Farm, Austin, Texas, USA (probably strain 3370.1 [University of Texas], currently strain 15081-1371.8 [University of Arizona]). b. Drosophila nigrospiracula Patterson \& Wheeler, 1942; specimen (no. 23) from Arizona, USA (strain 21.58.10 [University of Texas]). c. Drosophila paranaensis Barros, 1950; specimen (no. 623) from Tingo Maria, Department of Huánuco, Peru. d. Drosophila peninsularis Patterson \& Wheeler, 1942; specimen no. 29, from Havana Country Club, Cuba (strain 2377.2 [University of Texas], currently strain 15081.1401.11 [University of Arizona]). Scale bars $=0.1 \mathrm{~mm}$.
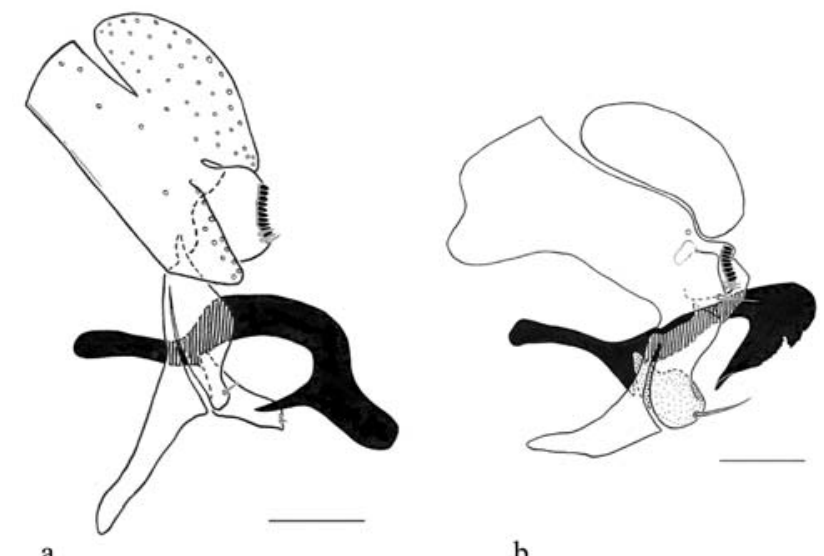

a

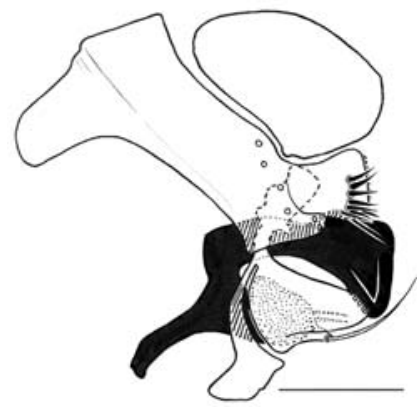

c

b

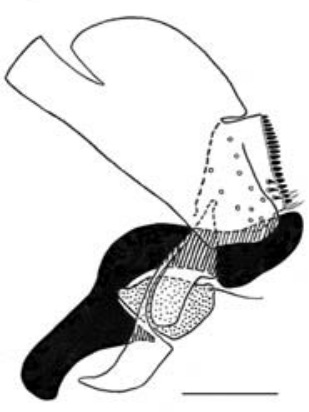

$\mathrm{d}$

Figure 9 - Male terminalia (aedeagus + aedeagal apodeme are highlighted in black, and paraphysis is highlighted with dots), left lateral view, of: a. Drosophila rosinae Vilela, 1983; specimen (no. 48) from Natal, State of Rio Grande do Norte, Brazil. b. Drosophila mediopunctata Dobzhansky \& Pavan 1943; Itanhaém, State of São Paulo, Brazil [holotype]. c. Drosophila mediostriata Duda, 1925; locality unknown. d. Undetermined Drosophila sp. 1; specimen (Pavan n.12, M [Marta?] n. 63) from Angra dos Reis, State of Rio de Janeiro, Brazil. Scale bars $=0.1 \mathrm{~mm}$.

\section{Acknowledgments}

Thanks are due to Mrs. Emelde Konradi for donating to the Departamento de Biologia, on July $31^{\text {st }}, 1993$, several of Marta Breuer's original drawings of Drosophila spp. male terminalia, in addition to some reprints, photographs, slides and other documents, which had been under her care since Mr. Grellet passed away; to the late Prof. Silvio de Almeida Toledo Filho and his son Eduardo Foresti de Almeida Toledo for accompanying one of us (CRV) during the visit to Mrs. Konradi; to Carlos J. E. Lamas, curator of Diptera at the Museu de Zoologia, for allowing the analysis of the microscope slide collection; to Maria Helena da Silva Leme for kindly searching and intermediating the loan of four of Marta's record files (n. 55.1.16582.1.9; n. 60.1.7276.1.1; No. 60.1.9093.1.1; n. 67.1.3685.1.0) housed at the main USP archives; to Elisa Pereira Knapp and her husband Walter Knapp for kindly allowing us to scan one fine photograph of their private collection (Figure 2), and for authorizing its publication in the present paper; to Marianne Erps Fleming (Marta's niece) for some precious bio- 
graphical information; to Crodowaldo Pavan, EPK and Beatriz Goñi for critically reading the manuscript; to Helenice Hirata for printing the figures.

\section{References}

Breuer ME (1967a) Cromossomos politênicos das glândulas salivares de Rhynchosciara angelae Nonato \& Pavan, 1951 (Diptera, Sciaridae). Rev Bras Biol 27:105-108.

Breuer ME (1967b) Rhynchosciara baschanti (Diptera, Nematocera, Sciaridae), a new Brazilian species. Pap Avulsos Zool 20:259-263.

Breuer ME (1969) Revision of the genus Rhynchosciara Rübsaamen (Diptera, Sciaridae) in the Neotropical region. Arq Zool 17:167-198.

Breuer ME (1971) Rhynchosciara papaveroi, a new Brazilian species (Diptera, Sciaridae). Pap Avulsos Zool 25:35-40.

Breuer ME and Pavan C (1950) Genitália masculina de Drosophila (Diptera): Grupo annulimana. Rev Bras Biol 10:469-488.

Breuer ME and Pavan C (1952) Gens na diferenciação. Ciênc e Cult 4:115.

Breuer ME and Pavan C (1954a) Genitália masculina de Drosophila do grupo dreyfusi (Diptera). Rev Bras Biol 14:465-475.

Breuer ME and Pavan C (1954b) Salivary chromosomes and differentiation. Proceedings of the IX International Congress of Genetics, p 778.

Breuer ME and Pavan C (1955) Behavior of polytene chromosomes of Rhynchosciara angelae at different stages of larval development. Chromosoma 7:371-386.

Breuer ME and Rocha RF (1971) Genitália masculina de algumas espécies de Drosophila dos grupos repleta e tripunctata (Diptera, Drosophilidae). Pap Avulsos Zool 25:121-137.

Cunha AB (1977) Marta Erps Breuer (1902-1977). Ciênc e Cult 29:951-952.

Dobzhansky T and Pavan C (1950) Local and seasonal variations in relative frequencies of species of Drosophila in Brazil. J Animal Ecology 19:1-14.

Dreyfus A and Breuer ME (1943) Unicidade ou dualidade dos machos de Telenomus fariai? Rev Bras Biol 3:431-441.

Dreyfus A and Breuer ME (1944a) Chromosomes and sex determination in the parasitic hymenopteron Telenomus fariai (Lima). Genetics 29:75-82.

Dreyfus A and Breuer ME (1944b) O sexo nos himenópteros arrenótocos: Biologia, determinação do sexo e ciclo cromossômico do microhimenóptero parasito Telenomus fariai
Lima. Boletins da Faculdade de Filosofia, Ciências e Letras 40, Biologia Geral 5:1-103.

Dreyfus A, Nonato E, Breuer ME and Pavan C (1951) Cromosomas politênicos em vários órgãos de Rhynchosciara angelae Nonato \& Pavan (Diptera). Rev Bras Biol 11:439450.

Gatje RF (2000) Marcel Breuer: A memoir. Monacelli Press, New York, $320 \mathrm{pp}$.

Pavan C and Breuer ME (1951) Análise comparativa de cromosomas politênicos de diferentes órgãos de Rhynchosciara angelae. Ciênc e Cult 3:299-300.

Pavan C and Breuer ME (1952) Polytene chromosomes in different tissues of Rhynchosciara. J Heredity 43:150-157.

Pavan C and Breuer ME (1954) Two new species of Drosophila of the dreyfusi group (Diptera). Rev Bras Biol 14:459-463.

Pavan C and Breuer ME (1955a) Differences in nucleic acids content of the loci in polytene chromosomes of Rhynchosciara angelae according to tissues, and larval stages. In: Symposium on Cell Secretion. Belo Horizonte, pp 90-99.

Pavan C and Breuer ME (1955b) Polytene chromosomes of Rhynchosciara milleri sp. n. (Diptera, Mycetophilidae). Rev Bras Biol 15:329-339.

Pavan C, Breuer ME and Basile R (1962) Síntese de ácidos nucleicos em cromossomos politênicos. Ciênc e Cult 14:215-216

Pilares LV and Vásquez JA (1977) Especies del Género Drosophila (Diptera) registradas para el Perú. Rev Per Entomol 20:103-106.

Rocha RF (1971) Drosophila breuerae, a new Neotropical species of the annulimana group (Diptera, Drosophilidae). Pap Avulsos Zool 25:139-142.

Throckmorton LH (1962) The problem of phylogeny in the genus Drosophila. Univ Texas Publs 6205:207-343.

Vilela CR (1983) A revision of the Drosophila repleta species group (Diptera, Drosophilidae). Rev Bras Entomol 27:1114.

Vilela CR and Mori L (1999) The genus Drosophila (Diptera, Drosophilidae) in the Serra do Cipó: Further notes. Rev Bras Entomol 43:319-328.

Wasserman M and Wilson FD (1957) Further studies in the repleta group. Univ Texas Publs 5721:132-156.

Wheeler MR (1981) The Drosophilidae: A taxonomic overview. In: Ashburner M, Carson HL and Thompson Jr JN (eds) The Genetics and Biology of Drosophila. v. 3a. Academic Press, London, pp 1-97.

Associate Editor: Fábio de Melo Sene 